\title{
TOURIST'S PROFILE AND PERCEPTION TOWARDS ECOTOURISM PRODUCT IN AMBENGAN VILLAGE, SINGARAJA, BALI
}

\author{
Komang Trisna Pratiwi Arcana ${ }^{1}$, Febianti ${ }^{2}$. \\ The International Bali Tourism Institute (STPBI). \\ trisnapratiwi.arcana@gmail.com
}

\begin{abstract}
The development of the tourism industry in the south of Bali tend to be uncontrolled and opened an opportunity for other development of alternative tourism destination in other regions of Bali such as Singaraja. One of destination with natural and cultural tourism attraction is Ambengan Village. In the increase of tourist demand, the community needs to do some innovations and development of tourism product. Furthermore, it requires to prioritize the existing market segmentation and reaching the other one. It necessary due to the existing product has some weaknesses compared to tourism product attributes. The objective of this research is to discover the tourist's profile and their perception of ecotourism product in Ambengan Village with qualitative and quantitative method. To obtain the data, the research instruments used were questionnaire to 100 mixes of domestic and international tourist, interview guidelines to government, village chief, local community, and checklist observation. Majority of the tourist were satisfied with natural attraction been offered, informative local people, and safety atmosphere surrounding area. The local community has been aware of tourism potential in their village. They are in the state of euphoria level. However it wasn't completed with other supported attributes such as accommodation; restaurant; accessibility; route direction; moneychanger and souvenir shop. Government needs to allocate more budgets in supervising the community to develop tourism potential. The data obtained also assists them practically to create marketing strategy and guidance of ecotourism product in Ambengan Village.
\end{abstract}

Keywords: tourist, perception, ecotourism, Ambengan Village

\section{INTRODUCTION}

Tourism has been trusted as one of the potential and eco-friendly industries in many countries. This phenomenon may be natural when you see a growing trend, where tourism has brought profits, both macro and micro. The latest data in 2016, the United Nations World Tourism Organization (UNWTO) noted that tourism has produced $9 \%$ of the Gross Domestic Product on an average world basis (both directly and indirectly). Whereas materially, this industry has opened jobs, where 1 in 11 jobs is related to tourism, besides this business has produced 1.4 trillion US\$ 
exports (6\% of total world exports). Therefore, the tourism industry is expected to increase in 2030 with the activity of 1.8 billion international tourists.

This global phenomenon has also affected the national scope, one of which is Indonesia. By looking at international tourism trends that are getting better, it is not surprising if the government in the previous Era, until now the presidential administration of Joko Widodo (2016-2019) supports this industry as the $4^{\text {th }}$ priority program from 8 to be developed in a country with $35 \%$ natural potential, $60 \%$ culture, and 5\% man-made. This potential certainly gives the government confidence through the tourism ministry to determine the target of tourist visits in 2019, with details of 20 million international tourists (an increase of more than $100 \%$ since 2014), and 275 million domestic tourists. With quite large achievement targets, the government continues to encourage the development of tourism infrastructure and ecosystems, as well as improving the quality and quantity of new destinations and carrying out various innovations in advanced destinations. Specifically, the program was sharpened through the acceleration of 25 national tourism strategic areas and 10 priority tourism destinations (Yahya, 2016).

In addition to the development in quantity, both the number of tourist growth and revenue receipts. The trend of tourist behavior in general also experienced a shift. Leksakundilok (2004: 97) noted that the phenomenon of tourism has shifted from the conventional form, which is characterized by mass tourism development developing towards the modern. However, this phenomenon in the present era has experienced development. Saturation and desires of tourists encourage the emergence of an era of alternative tourism. This form of tourism is a response to tourists' awareness of sustainability, both in terms of environment, economy, social and culture. So that later creates various types of new tourism products that are principled on sustainability values such as indigenous tourism, pro-poor tourism, ecotourism, adventure tourism, educational tourism, to community-based tourism (Guzmán et al., 2011: 69).

One of the regencies that have the potential for development with the concepts and principles of ecotourism in Bali is the Buleleng Regency. Tourism development in southern Bali is so rapid and tends to be out of control, opening up opportunities for other regions to develop their potential as alternative and more planned tourist destinations. One destination in north Bali that has tourism potential, both natural and cultural is Ambengan Village. Ambengan Village is one of the villages which have ecotourism potential located in Buleleng Regency precisely in Sukasada District. The position of Ambengan Village is on a green hill which is about $6 \mathrm{~km}$ south of Singaraja city. Ambengan Village has more than four waterfalls and several ponds that are formed naturally. In addition, people in Ambengan Village live in hilly areas with daily activities of raising livestock and farming with traditional systems (subak). The village community is also known as a craftsman of various souvenirs made of wood and bamboo. Like some traditional villages in Bali, Ambengan Village also has traditional arts and culture that are still maintained today.

The development of Ecotourism products in Ambengan Village can be said still relatively new, so if it is viewed through the concept of product life cycle or known as tourism product lifecycle, it can be said that this tourism product is still in the development phase (Arcana and Wiweka, 2016). This means that there are still aspects of the destination that can be developed. In the process of developing 
the quality of ecotourism in Ambengan Village, it is very important to see the response of tourists who have felt and have experience of ecotourism products in the village. This information can be the basis or main data for innovating ecotourism products in accordance with the principles of sustainable tourism.

The existence of ecotourism products in Ambengan Village can be an alternative attraction in North Bali, so the distribution of tourists becomes more balanced, especially compared to South Bali. However, the development of ecotourism products that can still be said to be in the development phase, the Ambengan Village needs to innovate and improve quality, especially from the product side. On this basis, it is necessary to study the profile and perception of tourists (both domestic and foreign) on ecotourism products in Ambengan Village at this time. This data is very useful as a basis for product development and innovation, as well as in determining marketing strategies and determining market segments in the future. Based on the background and identification of the problem above, it can be explained several research objectives as follows: a) Assessing available ecotourism products in Ambengan Village, Singaraja Bali, b) Identify profiles and characteristics of tourists (domestic and foreign) who visit ecotourism products in Ambengan Village, and c) Assess the perception of tourists (both domestic and foreign) on ecotourism products in Ambengan Village, based on tourist product forming attributes (6ACIT) consisting of attractions, accessibilities, amenities, ancillary, activity, available package, community empowerment (community involvement); investment; and technology.

\section{LITERATURE REVIEW}

Solomon (2001) stated the definition of perception as follow:

" ... as a process by in which the sensations are selected, organized, and interpreted. Furthermore, the sensation refers to the immediate response of the human sensory receptors, i.e.: eyes, ears, nose, mouth, skin to basic stimuli such as sights, sounds, smells, taste, and feelings...".

Based on the definition of perception above Solomon wants to give a perspective that one's perception is strongly influenced by the process of determining decisions in doing things and evaluating activities that involve the human senses. The process represents someone in responding to the surrounding environmental attributes (Reisinger, 2003). In other words, perception is very subjective depending on how someone assesses something based on the acceptance process, processes information, and interprets it.

The tourism industry is a combination of various disciplines and the industrial sector (Jafari in Goeldner and Ritchie, 2009: 24). The tourism industry also cannot stand alone without support from other sectors. The hope of being able to fulfill the desires of tourists while in a tourist destination begins with motivation or encouragement from within and often push factors. Pull factor consists of several supporting elements (Leiper, 1990 in Mason, 2003; Waver and Lawton, 2006). In the tourism economic perspective this component is called a supply or tourism product or tourism product. Subsequent developments, academics began to develop components of tourism product offerings called 4A (attraction; accessibility; amenities; and ancillary service) (Cooper et al., 1993) and currently developed into 
6A (Buhalis, 2000) with supporting attributes like attraction, accessibility; amenities; ancillary service; activity; and available package.

As the concept of sustainable tourism develops today as a result of the emergence of mass tourism and its coping efforts, various forms of alternative tourism appear (Arcana and Wiweka, 2016). One form of alternative tourism that develops is ecotourism. Ecotourism adopts several alternative tourism characteristics, especially in terms of the power of destination, preservation and development of local potential (Fennel and Dowling, 2003). For Buckley (1994), four dimensions of ecotourism are natural or natural based, supporting conservation, sustainable management, and education (environment). While Damanik and Weber (2006) added that ecotourism is "one of the special interest tours seen from the characteristics of its products and markets". As opposed to conventional tourism ecotourism is an activity that gives great attention to the sustainability of tourism resources.

Three basic concepts related to ecotourism operations according to From (2004) in Damanik and Weber (2006) are (1) having an outdoor travel agenda in natural areas that do not cause environmental damage. Travel activities do not damage or sacrifice flora and fauna and change the topography of land and environment by building buildings that are odd to the environment and culture of the local community; (2) tourism activities prioritize the use of transportation facilities that are created and managed by local communities; (3) international travel activities pay great attention to the natural and cultural environment. Tourists have the opportunity to learn directly from the local community by not seeming to be patronizing but try to reduce the visual of economic inequality that can have a negative impact if it is not able to be filtered properly by the local community.

\section{METHODOLOGY}

This research was conducted in Ambengan Village, Singaraja, Bali, Indonesia. The choice of the location of this research is based on several considerations, which are among others: a) The location is one of the tourist attractions that offer potential ecotourism products, because it has natural resources that are still maintained authenticity; b) Profile and perception data of tourists (domestic and foreign countries) on the constituent elements of ecotourism products in Ambengan Village can be implemented in a practical scope as supporting data in planning marketing strategies, especially in determining market segments and targets. The results of this study are also useful as data in considering the development of ecotourism products in Ambengan Village.

The type of data collected in this study is qualitative, consisting of data on the potential of ecotourism products in Ambengan Village and characteristic data of tourists (domestic and foreign) who visit Ambengan Village. To strengthen qualitative data, this study also uses quantitative data, such as the perception of tourists (domestic and foreign countries) on the constituent elements of ecotourism products, which consist of: attraction; accessibilities; amenities; ancillary; activity; available package; community empowerment; investment and technology.

The intended informant from the government circles came from the Buleleng Regency Tourism Office and from a number of villages chairmen, community leaders, village organizations such as tourism awareness groups, small 
community in Ambengan Village. In addition, this study also used samples of both foreign and domestic tourists by survey method. 100 samples were determined through surveys and structured interviews through people who were considered as key person in Ambengan Village. The stages of research on profile study and tourist perception on ecotourism products can be seen in Table 1 below:

Table 1. Stages of Research on Profile Study and Tourist Perception of

Ecotourism Products

\begin{tabular}{|c|c|c|c|c|}
\hline No & $\begin{array}{l}\text { Qualitative } \\
\text { Research Stages }\end{array}$ & $\begin{array}{c}\text { Data } \\
\text { Collection } \\
\text { Techniques }\end{array}$ & Analysis technique & $\begin{array}{c}\text { Target Research } \\
\text { Objectives } \\
\text { achieved }\end{array}$ \\
\hline 1 & $\begin{array}{l}\text { Orientation stage } \\
\text { or description } \\
\text { (grand tour } \\
\text { question). At this } \\
\text { stage, the data } \\
\text { obtained is in the } \\
\text { form of issues } \\
\text { about the } \\
\text { potential of } \\
\text { ecotourism } \\
\text { products in } \\
\text { Ambengan } \\
\text { Village }\end{array}$ & $\begin{array}{c}\text { In-depth } \\
\text { interviews, } \\
\text { observation, } \\
\text { literature } \\
\text { study, and } \\
\text { document } \\
\text { verification. }\end{array}$ & $\begin{array}{c}\text { Qualitative } \\
\text { Descriptive. } \\
\text { Where the } \\
\text { qualitative research } \\
\text { process can be } \\
\text { divided into several } \\
\text { parts, including the } \\
\text { first stage, } \\
\text { orientation or } \\
\text { description (grand } \\
\text { tour question). At } \\
\text { this stage } \\
\text { researchers describe } \\
\text { what is seen, heard, } \\
\text { felt, and asked. In } \\
\text { this stage, the data } \\
\text { obtained is quite } \\
\text { large, varied, and } \\
\text { not clearly arranged. }\end{array}$ & $\begin{array}{l}\text { Identify the } \\
\text { potential in } \\
\text { Ambengan Village } \\
\text { which can be } \\
\text { packaged as } \\
\text { ecotourism } \\
\text { products, based on } \\
\text { elements; } \\
\text { attraction; } \\
\text { accessibilities; } \\
\text { amenities; } \\
\text { ancillary; activity; } \\
\text { available package; } \\
\text { community } \\
\text { empowerment; } \\
\text { investment and } \\
\text { technology. }\end{array}$ \\
\hline 2 & $\begin{array}{l}\text { Reduction or } \\
\text { focus stages, } \\
\text { where at this } \\
\text { stage the focus } \\
\text { of the research is } \\
\text { tourists } \\
\text { (domestic and } \\
\text { foreign) who } \\
\text { visit ecotourism } \\
\text { products in } \\
\text { Ambengan } \\
\text { Village. }\end{array}$ & $\begin{array}{l}\text { Questionnaires, } \\
\text { in-depth } \\
\text { interviews, } \\
\text { literature } \\
\text { studies, and } \\
\text { document } \\
\text { verification. }\end{array}$ & $\begin{array}{l}\text { Qualitative } \\
\text { Descriptive. } \\
\text { Determine the focus } \\
\text { on a particular } \\
\text { problem and make a } \\
\text { selection where data } \\
\text { is interesting, } \\
\text { important, useful, } \\
\text { and new. Unused } \\
\text { data will be } \\
\text { removed, while used } \\
\text { data will then be } \\
\text { classified into } \\
\text { various categories } \\
\text { that are designated } \\
\text { as research focus. }\end{array}$ & $\begin{array}{c}\text { Identifying } \\
\text { profiles and } \\
\text { characteristics of } \\
\text { tourists (domestic } \\
\text { and foreign) } \\
\text { visiting ecotourism } \\
\text { products in } \\
\text { Ambengan } \\
\text { Village. }\end{array}$ \\
\hline
\end{tabular}




\begin{tabular}{|c|c|c|c|c|}
\hline 3 & $\begin{array}{l}\text { The selection } \\
\text { process in which } \\
\text { researchers } \\
\text { examine the } \\
\text { focus of research } \\
\text { in more detail. } \\
\text { This is done by } \\
\text { analyzing the } \\
\text { perception of } \\
\text { tourists } \\
\text { (domestic and } \\
\text { foreign) on } \\
\text { ecotourism } \\
\text { products in } \\
\text { Ambengan } \\
\text { Village. }\end{array}$ & $\begin{array}{l}\text { Questionnaires, } \\
\text { in-depth } \\
\text { interviews, } \\
\text { literature } \\
\text { studies, and } \\
\text { document } \\
\text { verification. }\end{array}$ & $\begin{array}{l}\text { Qualitative and } \\
\text { Quantitative } \\
\text { Descriptive. } \\
\text { Review or analyze } \\
\text { the data and } \\
\text { information with } \\
\text { theories related to } \\
\text { the focus of the } \\
\text { problem. }\end{array}$ & $\begin{array}{l}\text { Determine the } \\
\text { perception of } \\
\text { tourists (domestic } \\
\text { and foreign) on } \\
\text { ecotourism } \\
\text { products in } \\
\text { Ambengan } \\
\text { Village. }\end{array}$ \\
\hline
\end{tabular}

\section{General Description of Research Objects}

RESULTS AND ACHIEVED OUTPUT

Ambengan Village is one of the villages in Buleleng Regency, precisely in Sukasada District. The position of Ambengan village is on a green hill which is about $6 \mathrm{~km}$ south of Singaraja city. Because it is located in a hilly area and the majority of the population is farming, this village is decorated with a very beautiful expanse of rice fields. In addition to its potential terrace, Ambengan also has more than four waterfalls and several natural and quite wide and very exotic ponds which are often referred to as a hidden park, where tourists can swim while enjoying a fresh atmosphere.

The administration of Ambengan village is located in Sukasada district, Buleleng Regency with an area of $13,69 \mathrm{~km}^{2}$, with the boundaries of the area which are north of Sukasada Village, south of Government Forest and Git-git Village, east of Padangbulia Village, and west of Sambangan Village. There are four hamlets (Banjar) in Ambengan Village, namely: Ambengan hamlet; Bukit Balu hamlet; Jembong hamlet; and Pebantenan hamlet. Whereas based on the natural boundary of the entire village Ambengan borders the topography of the mountains that stretch around the village.

Ambengan Village has been established as a tourist village since 2015 based on the Regent's Decree, because the natural potential indicated is capable of being an attraction of its own ecotourism. Furthermore, as a requirement to become a tourism village, a Tourism Awareness Group (Pokdarwis) was formed as the tourism industry management team. Pokdarwis in Ambengan Village named Banten Sari. This Tourism Awareness Group was pioneered in 1998. The background of the formation of the Darwis Group was due to the very attractive potential of Ambengan Village but lack of awareness of tourism. Banten Sari Tourism Awareness Group is facilitated by the Village chairman, Kelian Desa Adat, the government apparatus in Sukasada district. Juridically, followed up with the publication of the Decree of the Head of the Buleleng Regency Culture and Tourism 
Office Number: 04/Disbudpar/2007, on January 19, 2008. Currently the Chairperson of Banten Sari Tourism Awareness Group Ambengan Village is Mr. Made Suneka (45 years), he is also an entrepreneur.

Based on the results of an interview with the Chairman of Banten Sari Tourism Awareness Group, Ambengan Village, Mr. Made Suneka (45 years) on April 14, 2018, the development of tourism in Ambengan Village began in 2013, where tourism development efforts have been carried out by other tourism groups. in Ambengan Village. However, this has not provided maximum results. So that through the Ambengan Tourism Awareness Group, which is now led by Mr. Made Suneka, tourism development efforts are carried out, especially in the Banjar Dinas of Jembong, which has started since 2013 until now.

History of the formation of tourist villages in the village of Ambengan added by the presentation of Mr. I Gede Suberata (45 years) as the Perbekel (chairman) of Ambengan Village (interview results on April 30, 2018), where the community is aware of the natural potential that can become a tourist attraction. Following are the results of an interview with Mr. I Gede Suberata (45 years):

“... The history of Ambengan Village has become a tourist village, because we see Ambengan Village has the potential that there are natural resources such as panoramas. There are tourism objects such as the waterfall, that is the main basis for becoming a tourism village in Ambengan village. Because at first the Ambengan village had 3 waterfalls, namely in Banten Sari, Aling and Kroya, and Jembong waterfalls. Then in addition, Ambengan village has a mountainous area, so guests who do trekking can see panoramic panoramas in Ambengan village, such as rice fields, plantations and others. Besides that, in Ambengan village there are many handicrafts, such as banana midrib crafts, types of woven bamboo, so guests are more interested in craftwork. In 2015, the village of Ambengan was automatically bound by a Decree from the Regent to become a Tourism Village".

Besides mountains and natural scenery, Ambengan Village is also supported by the potential of plantations which from the beginning became the livelihoods of the residents there. When entering the village area, visitors can easily find a clove tree on the side of the road which is a local plantation. Besides cloves, various trees can also thrive in Ambengan Village such as durian, mango, coffee, chocolate, coconut and guava. If it is developed further, it can certainly be a $\mathrm{n}$ attractive tourism attraction for tourists. The regional potential map for Ambengan Village can be seen in Figure 1: 


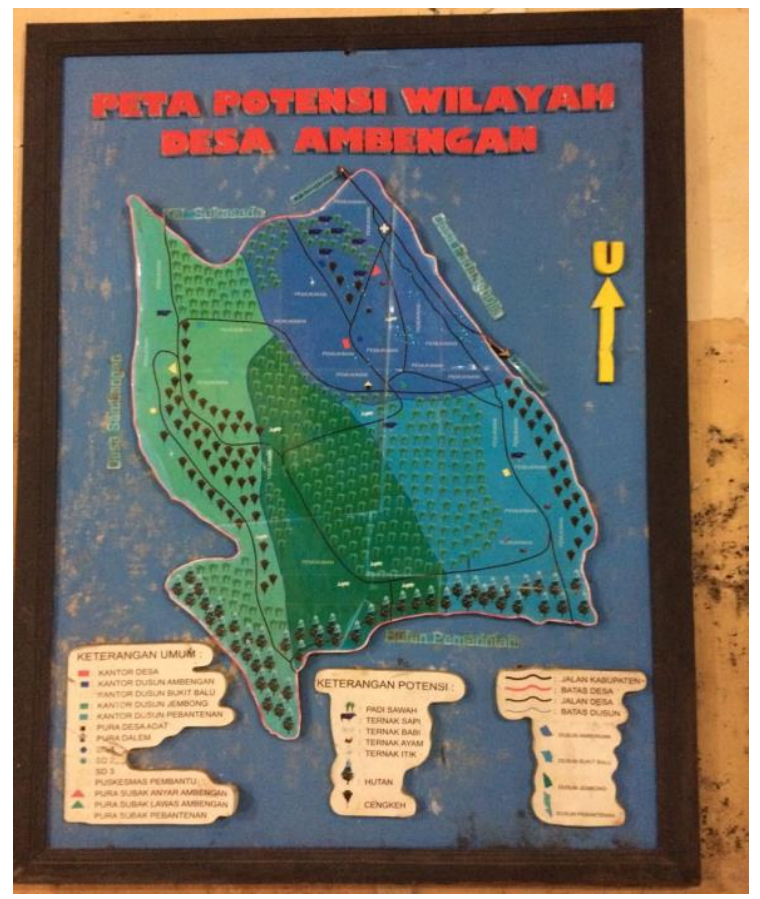

Figure 1 The Regional Potential Map of Ambengan Village

\section{Potential Ecotourism Products in Ambengan Village, Singaraja, Bali}

Ecotourism is a tourism activity that gives great attention to the sustainability of tourism resources. Adopting several definitions from experts, ecotourism can be interpreted as one form of alternative tourism that offers forms of activities and travel experiences that are close to nature, local culture that is loaded with educational value as the main attractions offered. The characteristics of ecotourism are quite different from mass tourism, especially in tourism activities, where ecotourism has a motive for environmental conservation because tourists have the awareness to participate in preserving the environment. Environmental awareness encourages and makes it easier for tourists to be involved in conservation efforts. In addition to tourists, service providers also have the opportunity to help tourists to better appreciate the environment in the travel program that was prepared. This different tour program can be unique and give more value in traveling. In addition, income derived from tourism can also be set aside for environmental conservation programs so that the relationship between communities and conservation actors is tighter and more tangible.

The development of ecotourism products refers to the principles of nature conservation, culture, and the involvement of local communities in tourism activities. Ambengan Village as stated by Perkebel Desa, Mr. I Gede Suberata (45 years) and Chairperson of Tourism Awareness Group (Pokdarwis), Mr. Made Suneka (45 Years) has the potential of natural and cultural tourism which makes it one of the tourist villages in Bali in 2015. Having the potential of ecotourism products alone is not enough to develop the tourism industry; even Ambengan Village needs to design tourism products to meet market needs. The following is a study of ecotourism products in Ambengan Village.

The main tourist attraction of Ambengan Village is nature and culture. Ambengan Village has unique characteristics and abundant natural resources. This is because the location is surrounded by government conservation forests and is limited by rivers with 12 waterfalls, 6 of which are named. Whereas cultural attraction in the 
form of art activities held in each ceremony activities such as dances, percussion art and some crafts that are now the livelihoods of local residents.

The village itself is easily accessible by transportation route. However, to go directly to natural attractions, you must use an ojek or private vehicle, because it is about $5 \mathrm{~km}$ from the village entrance. Access to attractions is currently in a condition that is good enough or can be traversed by two-wheeled and 4-wheeled vehicles. To reach Ambengan Village from Singaraja only takes about 5 minutes, while from Denpasar City it takes around 2 hours. Road access to each waterfall is classified as a provincial road made of hotmix asphalt which was initially in good condition and there were rarely any damages such as bumpy roads or holes. However, because a lot of large vehicles such as buses and trucks are being traversed, the road conditions in Ambengan Village began to worsen. Although the damage is not as severe as the previous conditions, it needs further handling considering that tourist attractions in Ambengan Village are now well known to local and foreign tourists.

General supporting infrastructure that can be used for tourism activities in Ambengan Village, including; warung, traditional market, ojek (motorbike taxi) base located at the entrance of the village and also the bus terminal (Sangket terminal) which is located in Sukasada District, about $4 \mathrm{~km}$ from the village. Some constraints from the aspect of facilities are the unavailability of quality and standard public toilet facilities, which may become an inconvenience for tourists. Whereas for tourists who want to spend the night or stay in Ambengan village, local people provide lodging facilities by utilizing their private homes that are managed according to their habits and are not intended specifically for tourism businesses. Until now, efforts to provide accommodation in Ambengan Village have not yet been carried out. But there are accommodations such as Hotel Pop Haris and Bungalow in the Gitgit area which are located not too far from Ambengan Village. In addition to accommodation facilities there are also health centers and hospitals around Ambengan Village. Another obstacle is the unavailability of Money Changer or ATM Machine in tourist destinations. There is also a counter where entrance tickets are purchased at Jembong Waterfall. But not all attractions provide ticket tickets where tourists can write their own data. The written personal data is still manual using the ledger but at least it has been provided so that the manager will get an overview of the profile of the tourists present.

In addition to providing infrastructure to support tourism, destinations also need to develop various types of activities that can be carried out by tourists during a visit. These activities are a step to bring tourists and tourist attractions closer. This involvement will give a deep impression to tourists visiting a destination. Among those activities are seeing natural landscapes, photography, recreation, cycling, hiking, meditation, tracking, swimming, and free jumping. Tourism activities have also begun to attract local people to get involved in the tourism business, such as travel agents. This will have multiple impacts from an economic point of view.

Some tourist destinations provide additional service centers, both in the form of public and private organizations. In the local sphere, these organizations generally have the following functions: marketing a destination, coordinating and supervising the development of tourist destinations, and coordinating with business stakeholders. Whereas in Ambengan Village, a part of the Waterfall was managed by Banten Sari Tourism Awareness group, in Ambengan Village and directly under 
the supervision of the Jembong Regional Coordinator headed by Mr. Putu Sunada. From the results of interviews with the management of the Jembong Waterfall, the participation of the local government of Buleleng Regency, especially the Buleleng Regency Culture and Tourism Office in the development of Jembong Waterfall Natural Tourism is not yet maximal. The village community in its management only relies on the mutual cooperation activities of the local community and selected community groups. Until now there is no cost (either in the form of donations or entrance tickets) charged to tourists who come to visit the attraction of the Waterfall. This is due to the absence of physical arrangements and promotional activities.

\section{Characteristic and Perception of Tourist Visiting Ambengan Village}

Tourist profiles show that tourists with a higher intensity visit Ambengan Village are students and workers with an average income of 5,000,000 per month and unmarried status. $63 \%$ of tourists are male and $84 \%$ are domestic tourists from Bali. This shows that the popularity level of Ambengan Village ecotourism products is still unable to reach tourists from outside Bali and abroad. This can be seen from the number of foreign tourists who come only around $16 \%$. Besides that, some of the main requirements and supporters of tourist destinations have also not been fulfilled such as accommodation, eating places, or decent toilets, especially for foreign guests who are quite large considering the cleanliness of toilets in tourist destinations. Meanwhile, when viewed from the high percentage of visitors (male) caused by the types of natural attractions that offer accessibility, it still needs to be considered because the roads are still rocky, even the main access to tourist attractions that are not easy to reach and require special interest for tourists who like adventure or adventure.

The average tourist interest in adventure tourism is male. This is also in line with the motivation of visiting the destination, which is primarily to relax thoughts and explore new places or things. Ambengan Village offers beautiful landscape and it also becomes a great indicator that can help people release the mind from the saturation of a big city or routine. Nature is the highest medium capable of helping humans to release emotions in the human subconscious so that Ambengan Village is a suitable place to fulfill this motivation.

To determine the characteristics and perception of tourist visiting Ambengan Village, a survey of 100 respondents consists of tourists visiting Ambengan Village was conducted. Respondents gave an assessment of 12 indicators that motivated tourists to visit Ambengan Village with a 5-point Likert Scale. There are 5 categories of answer choices in the questionnaire, namely Strongly Disagree with a score of 1, Disagree with a score of 2, Neutral with a score of 3, Agree with a score of 4, and Strongly Agree with a score of 5. The results of the questionnaire about the characteristic of tourist motivation in visiting Ambengan Village indicate that based on the average/mean (M ) the answer, the biggest motivation is to relax the mind with the mean of 4.71 , along with the desire to explore a new place $(\mathrm{M}=4.63)$ and increase knowledge $(\mathrm{M}=4.61)$.

Some indicators have a range of adjacent averages, namely the motivation to get out of the daily routine $(M=4.4)$, find a quiet place $(M=3.9)$, add experience $(M=4.38)$, and see how people's lives in the village Ambengan $(M=4.23)$. The next average range is in the following indicators: look for identity (identity) with 
the number 4.06, grow a sense of spirituality with the number 4.03, and Relax Physically with an average of 4.02. Two indicators get a low average score compared to other indicators, namely using free time with friends $(M=3.79)$, and only joining with others $(\mathrm{M}=3.35)$.

In determining tourist perception of ecotourism attractions, respondents gave an assessment of 27 things that can be found in Ambengan Village by tourists. Respondents gave an assessment using the Very Not Important category with a score of 1, Not Important to Score 2, Neutral with a Score of 3, Important with a Score of 4, and Very Important with a Score of 5 against each factor. Through the results of the questionnaire, tourists' perceptions of the most influential factors as a determinant of travel decisions can be obtained to visit the Ecotourism Object in Ambengan Village. By calculating the mean / mean score of the total value of each factor, it was found that Aling-Aling Waterfall as a tourist attraction in Ambengan Village was the most important factor for tourists with an average of $M=4.55$. Ambengan Village relies on ecotourism so that the cultural village factors, natural scenery, terracing, natural attractions, adventure attractions, and a clean environment get a high rating with an average range of $\mathrm{M}=4.43$ to $\mathrm{M}=4.5$, although the Ambengan Village landscape as a whole gets more value low with $\mathrm{M}$ $=4.28$.

Based on social aspects, the existence of an information center is supported by friendly people, honest and courteous people, and the interesting life of local people is a further factor that is considered important by tourists with an average range of $\mathrm{M}=4.35$ to $\mathrm{M}=4.39$. Safety and security factors in Ambengan Village also received a high rating with $\mathrm{M}=4.45$. Followed by the attitude of the workers $(M=4.18)$ and reasonable prices and services $(M=4.17)$. Although included in the important category with $\mathrm{M}=4.08$, the access / range (distance) factor is not a barrier for tourists' decision to visit Ambengan Village. Likewise, with amenities factors such as Accommodation $(\mathrm{M}=3.88)$, Tourism Facilities (Accommodation; Restaurants; Money Changer; Tour Guide) $(\mathrm{M}=3.85)$, and souvenir shops $(\mathrm{M}=$ 3.53) occupy a lower position in determining tourist visiting decisions.

Factors of cultural diversity in Ambengan Village $(\mathrm{M}=4.15)$ occupy a lower position than the natural attraction factor of Ambengan Village, seen through the average results of religious festivals / events / ceremonies $(\mathrm{M}=4.07)$, artificial attractions $(M=4.03)$, religious places $(M=3.78)$, historical buildings $(M=3.74)$, architecture $(\mathrm{M}=3.41)$, and art (music / dance) $(\mathrm{M}=3.33)$. Tourists also do not consider people of royal descent as an important factor in visiting Ambengan Village, so that these factors occupy the lowest position with an average of $\mathrm{M}=$ 3.04 .

In the aspect of tourist satisfaction, 100 respondents gave an assessment of 5 (five) variables and their respective indicators consisting of: natural attractions, accessibility, supporting facilities, travel agents; tour guide \& availability of tour packages, ancillary services and local community involvement. The assessment uses a 5-point Likert Scale in the Very Dissatisfied category with a score of 1, Dissatisfied with a score of 2, Neutral with a score of 3, Satisfied with a score of 4, and Very Dissatisfied with a score of 5.

The level of tourist satisfaction with natural attractions in Ambengan Village was measured with 7 component indicators. In the component of natural attractions, more than 50 percent of respondents give a score of 5 on each indicator. The average 
calculation results show that tourists feel most satisfied with tourist facilities in Ambengan Village with $M=4.72$. The availability of information about tourist attractions and service quality ranks next with the same average that is $M=4.67$. The level of security is in the middle position with $\mathrm{M}=4.65$, followed by cleanliness and components of tourism products with $M=4.56$. Diversity is at the bottom with $\mathrm{M}=4.43$

The next result shows the level of tourist satisfaction on accessibility in Ambengan Village using 4 indicators. From the results of the questionnaire, 22 percent of respondents gave a score of 5 (very satisfied) and 63 percent gave a score of 4 (satisfied) with cleanliness in Ambengan Village $(\mathrm{M}=4.04)$. Furthermore, the affordability of Ambengan Village gets almost the same average results $(\mathrm{M}=3.77)$ with the availability of road instructions $(M=3.76)$. At the lowest position, as many as 31 respondents stated neutral (score 3 ) and 46 percent expressed satisfaction (score 4) in the level of satisfaction in the ease of reaching the object of ecotourism $(M=3.62)$. This shows that although tourism objects in Ambengan Village are generally still affordable and have been equipped with road instructions, tourists are not yet fully satisfied with the ease of access in Ambengan Village.

The level of tourist satisfaction with various tourism supporting facilities found in Ambengan Village is measured using 12 indicators. Respondents were satisfied with the availability of hospitals and the like in Ambengan Village with $\mathrm{M}=4.07$. The availability of transportation rentals (motorbike, bus, car, or bicycle) gets a level of satisfaction similar to $M=4.04$, which makes it easier for tourists to travel around the village. Respondents felt quite satisfied with comfort and safety when visiting Ambengan Village with $\mathrm{M}=3.98$. Likewise, the quality of service $(\mathrm{M}=$ 3.98) given in various tourist facilities followed by price matching $(M=3.72)$. The ability of the Ambengan Village HR in foreign languages (English; Japanese; French; Mandarin; Spanish) is considered to be quite good $(\mathrm{M}=3.82)$ so as to facilitate communication with tourists.

The level of satisfaction of tourists looks less towards the accommodation facilities offered by Ambengan Village. Respondents stated that the level of satisfaction that was not optimal for the availability of places to stay such as hotels, villas, homestays, bungalows, cottages $(\mathrm{M}=3.54)$ and restaurant availability $(\mathrm{M}=3.51)$. Then the bedroom facilities (bed, bathroom, tv, internet; food \& beverage services) offered by the available places of residence have not been able to meet the standards and expectations of tourists with an average level of satisfaction that is $\mathbf{M}=3.59$. Finally, tourists seem quite difficult to exchange their currency into Rupiah as seen from the availability of money changers which get the lowest rating with $\mathrm{M}=3.46$. Result for the level of tourist satisfaction with travel agents, tour guides and the availability of tour packages that offer Ambengan Village as one of the ecotourism destinations was determined using 9 indicators. Referring to the average calculation results, the quality of available information has the highest value with $\mathrm{M}=4.47$. Tourists also feel satisfied with comfort $(M=4.28)$ and security $(M=4.43)$ during their tour activities in Ambengan Village. While human resources such as tour guides are considered to have a high level of friendliness $(\mathrm{M}=4.40)$ and professionalism $(\mathrm{M}=4.33)$, it's just not balanced by the level of foreign language skills that only get $M=3.93$. A fairly low assessment was obtained on the availability of tour packages, where the three indicators, namely the diversity of tour packages $(M=3.79)$, the flexibility of travel packages $(M=3.77)$, and the 
variation of travel packages $(\mathrm{M}=3.55)$ designed by travel agents required a variety of activities. more diverse and can adapt to the wishes of tourists

The level of tourist satisfaction with the availability of ancillary services in Ambengan Village is determined using 6 indicators. Respondents expressed satisfaction with the availability of tourist information with $M=4.26$ and the availability of hospitals with $\mathrm{M}=4.10$. However, other indicators have a lower level of satisfaction. Respondents considered that the availability of post offices $(\mathrm{M}=$ 3.73), money changers $(M=3.60)$, souvenir shops $(M=3.43)$ and banks $(M=3.29)$ are still difficult to find in Ambengan Village.

The last aspect is the level of tourist satisfaction with the involvement of local communities using 6 indicators. From the results of the average calculation, all indicators get a high rating from the respondents. Respondents expressed satisfaction with the concern of the local community for the environment with $\mathrm{M}=$ 4.69. Hospitality $(M=4.63)$ and honesty $(M=4.60)$ local people towards tourists $(\mathrm{M}=4.63)$ also influence in helping to form a comfortable atmosphere $(\mathrm{M}=4.64)$. Respondents were also satisfied with the attitude of the informative local community $(\mathrm{M}=4.42)$ and had foreign language skills $(\mathrm{M}=4.51)$ so that communication was smooth, especially with foreign tourists.

\section{CONCLUSION AND SUGGESTIONS}

The rapid development in South Bali opens up opportunities for other parts of Bali to develop tourism potential. Different from conventional tourism concepts, sustainability concept produces several forms of alternative tourism, one of which is ecotourism. In Buleleng Regency, one of the tourist villages that have ecotourism potential is Ambengan Village, precisely in Sukasada District. Ambengan Village has more than four waterfalls and several ponds that are formed naturally. Besides that the people also have cultural tourism attractions called Ngulah or Makepung which are carried out every time harvesting rice besides The community also expands the artificial facilities to accommodate the Jembong waterfall in the pool so that tourists and the local community can interact and enjoy the clear and fresh waterfalls with easier and more convenient access. In addition, the community also provides trekking facilities for tourists who want to see first-hand the life of the local community of Ambengan Village.

The level of tourist satisfaction on ecotourism products in Ambengan Village shows that tourists feel most satisfied with the facilities of natural attractions where counters are available, parking areas are quite spacious, information centers, places to rest and also toilets although not clean enough and comfortable but available to tourists who want to change clothes too. While the level of satisfaction with accessibility shows the highest value for the access hygiene component and the distance away from the city of Denpasar is not a significant problem to visit this new destination.

The existence of supporting facilities such as hospitals and rental of transportation in tourist destinations is also a major consideration but the focus or obstacle is the absence of restaurants and money changers around the destination to help make it easier if you want to shop. Besides that, souvenir shops are not yet available so that the community has not been able to enjoy the handmade products of Ambengan Village. Judging from the availability of information in tourist destinations, tourists 
expressed great satisfaction because the Pokdarwis were able to provide explanations and share tasks to be on guard at the location if tourists came. This indirectly gives a sense of security when tourists come to visit.

The community is expected to feel comprehensively the benefits of the tourism industry while still carrying the sustainable concept that is in line with the concept of Tri Hita Karana (Balinese Local Wisdom) so that it is not too far different from the vision and mission of the Buleleng Regency culture and tourism in the 20132017 periods. The local community is able to show their concern to tourists for the environment so that the beauty and green land in the destination even though some supporting and additional facilities are still built are still available and able to be maintained properly. This shows their concern for nature that has given them livelihood. Besides that harmony with the Creator is also showed with the presence of a Prayer Place in every tourist destination to give a sense of spiritual security and the natural balance that is believed by the local Balinese people.

The efforts to promote ecotourism products can be accompanied by arranging event tourism and inviting local governments, experts, academics, and investors to assist in the development and construction of several major facilities and supporting tourist destinations. The community can submit the Village Development Fund to the government to build the main supporting facilities for tourist destinations such as tourist accommodation, restaurants, clean and standard toilets, souvenir shops and other supporting facilities such as English language guides and Money Changer. If Pokdarwis wants to reach foreign markets then at least this facility can be provided.

Local communities need to improve their foreign language skills because the ecotourism destination in Ambengan Village is quite crossed by tourists from Europe even though it is still not in large numbers. European tourists do tend to like destinations that offer natural beauty and activities carried out in nature. So that adventurous ecotourism products in Ambengan Village can be additional value for the industry's managers. Tourism Awareness Groups can arrange a tour package or Full Day Activities in Ambengan Village by working together between hamlets to compile a comprehensive or comprehensive travel agenda and form unforgettable experiences for tourists. The Ambengan Village community can invite academics and experts to help promote Ecotourism products by creating a promotional media both online and offline and working with Travel Agents to market tourism products and add them to tour packages in Buleleng Regency.

\section{REFERENCES}

Anonymous. 2015. “Data Kunjungan Wisatawan Pada Kota Atau Kabupaten Di Bali". Date of access: 05/01/2015. http://www.disparda.baliprov.go.id/informasi/2013.

Antara, M., Kama Wijaya, G. N., Windia, W., 2017. “Ekowisata Subak, Jatiluwih, Tabanan, Bali" (Bali: Pelawa Sari)

Trisna Pratiwi Arcana,K., 2014. "The Implementation of Sustainable Event Management Concept Into MICE Management At Nusa Dua Resort, Bali”. Master Thesis. Postgraduate Studies, Udayana University, Denpasar. 
Trisna Pratiwi Arcana,K., Wiweka, K., 2016. "The Potential Development of Community Based Tourism at Ambengan Village, Buleleng Regency, Bali". E-Journal Business of Hospitality and Tourism (JB-HosT). 1 (1): 157 - 167.

Buckley, R., 1994. "A Framework For Ecotourism". Annals of Tourism Research $21(3), 61-665$.

Buhalis, D., 2000. "Marketing The Competitive Destination Of The Future". Tourism Management 21: 97 - 116. Date of access: 17/08/2013. www.elsevier.com/locate/tourman.

Cooper, Chris., et.al. 1993. "Tourism Principles and Practice" (England: Longman)

Cohen, Erick., 1972. Toward a Sociology of Internasional Tourism, Social Research, 39: 1 (1972: Spring).

Damanik, J, dan Weber, H. F., 2006. "Perencanaan Ekowisata: dari teori ke Aplikasi”. (Yogyakarta: CV ANDI OFFSET)

Fennell, David A., Ross K. Dowling. 2003. "Ecotourism Policy and Planning" (Australia: CABI Publishing)

Goeldner, Charles R., and J.R. Brent Ritchie. 2009. "Tourism Principles, Practice, and Philosophies". Eleventh Edition (New Jersey: John Wiley \& Sons, Inc)

Guzmán et al. 2011. "Community - Based Tourism In Developing Countries: A Case Study. Tourismos: An International Multidisciplinary Journal of Tourism". Volume 6, Number 1. University of Córdoba, Víctor PavónUniversity of Córdoba.

Grobler, Jan Harm Fouché. 2005. "Community Perceptions of Tourism in The Tshivhase Area, Limpopo Province". Doctoral Dissertation. Pretoria: University of Pretoria.

Jennings, Gayle. 2001. "Tourism Research”. Australia: John Wiley \& Sons Australia, Ltd.

Kusmayadi. dan Sugiarto, Endar. 2000. "Metodologi Penelitian dalam Bidang Kepariwisataan”. Jakarta: PT. Gramedia Pustaka Utama.

Leiper, Neil. (1979). The Framework of Tourism: Towards a Definition of Tourism, Tourist, and the Tourist Industry. Annals of Tourism Research, VI(4):390407.

Leksakundilok, Anucha. 2004. "Community Participation In Ecotourism Development In Thailand". Thesis. Australia: University Of Sidney.

Mason, Peter. 2003. "Tourism Impacts, Planning and Management". (Oxford: Butterworth - Heinemann.)

Nurlena. 2016. "Tourist Perception of The Tourism Products in Merangin Geopark, Jambi, Indonesia". E-Journal Business of Hospitality and Tourism (JBHosT). 2 (1).

Ratna, N. K. 2010. "Metodologi Penelitian Kajian Budaya dan Ilmu Sosial Humaniora pada Umumnya” (Yogyakarta: Pustaka Pelajar)

Reisinger, Y. and Turner, L. 2003. "Cross-Cultural Behaviour In Tourism: Concepts And Analysis." (Oxford: Butterworth and Heinemann)

Resmayasari, Ira. 2012. "Persepsi Wisatawan Perancis terhadap The Island of Paradise”. Master Thesis. Universitas Udayana: Bali.

Robbins, S.P. 2005. “Organizational Behavior" (New Jersey: Prentice Hall)

Robbins, S.P. \& Coulter, M. 2005. "Management" (New Delhi: Prentice Hall)

Stewart, R. 1979. "Person Perception and Stereotyping” (UK: Farnborough) 
Solomon, M.R. 2001. “Consumer Behaviour: Buying; Having; Being”. $5^{\text {th }}$ Edition (New Jersey: Prentice Hall)

Solomon, M.R. 2002. "Consumer Behaviour: Buying; Having; Being”. $3^{\text {rd }}$ Edition (Englewood Cliffs, NJ: Prentice Hall)

Sugiarto, et al. 2015. "Metodelogi Penelitian Hospitality dan Pariwisata (Jakarta: Matana Publishing)

Sugiyono. 2007. "Metode Penelitian Pendidikan (Pendekatan Kuantitatif, Kualitatif, dan R\&D”. 3rd Edition (Bandung: Alfabeta)

The International Ecotourism Society. 2000. "Ecotourism Statistical Fact Sheet". Date of access: 24/06/2017. www.active-tourism.com.

Tribe, John. 2009. "Aspects of Tourism, Philosophical Issues In Tourism" (UK: Channel View Publications)

TripAdvisor. 2017. "Pulau Bali di Indonesia adalah Destinasi Favorit". Date of access: 05/05/2017. www.tripadvisor.co.id/Tourism-g294226-BaliVacations.html.

United Nation World Tourism Organization. 2016. "International Tourist Arrivals Up 4\% Reach a Record 1.2 Billion in 2015". Press Release. Date of access: 20/01/2017. www.unwto.org.

Weaver, David. 2002. "Ecotourism" (Australia: John Wiley \& Sons, Milton)

Weaver, David. dan Laura Lawton. 2006. "Tourism Management". $3^{\text {rd }}$ Edition (Australia: John Wiley \& Sons Australia, Ltd.)

Wijayanti, Pini, Tanti Novianti, dan Hastuti. 2008. "Analisis Ekonomi dan Strategi Pengelolaan Ekowisata (Studi Kasus Kawasan Wisata Gunung Salak Endah Kabupaten Bogor)”. Jurnal Ilmu Pertanian Indonesia. 13 (3): 173 - 181.

Wiweka, Kadek dan Komang Trisna Pratiwi Arcana. 2017. "Rethinking the Theory of Tourism: What is Tourism System in Theoretical and Empirical Perspective?". Proceeding. 15 ${ }^{\text {th }}$ Asia Pacific Council on Hotel, Restaurant, and Institutional Education 2017.

Yahya, Arief. 2016. "A New Approach to Wonderful Indonesia". Presented in Asia Tourism Forum, Bandung 2016. Tourism Minister of Republik Indonesia. 